\title{
PERFORMANCE EVALUATION AND VARIABILITY ANALYSIS FOR MAJOR GROWTH AND FLOWERING TRAITS OF Lilium longiflorum THUNB. GENOTYPES
}

\author{
Rameshwar Rai ${ }^{1,2}(\mathbb{D})$, Jong Hwa Kim ${ }^{1,2^{*}}$ (D)
}

${ }^{1}$ College of Agriculture and Life Sciences, Department of Horticulture, Kangwon National University(KNU), Chuncheon 24341, Korea

${ }^{2}$ Oriental Bio-herb Research Institute, Kangwon National University, Chuncheon 24341, Korea

Received - June 29, 2021; Revision - August 11, 2021; Accepted - August 29, 2021

Available Online-August 30, 2021

DOI: http://dx.doi.org/10.18006/2021.9(4).439.444

\section{KEYWORDS \\ L. longiflorum \\ Genotypic coefficient of variation \\ Phenotypic coefficient of variation}

Heritability

Genetic advance

\begin{abstract}
The performance evaluation and variability estimation are some of the most important basic steps in any breeding scheme and are usually taken as a pre-breeding task. This experiment was carried out to evaluate the performance and estimate the variability for major growth and flowering traits of Sixteen Lilium longiflorum Thunb genotypes in a randomized complete block design (RCBD) with three replications. The estimated analysis of variance (ANOVA) demonstrated prevailing significant variability for studied ten growth and flowering traits of all 16 genotypes. The experiment was conducted to quantify the genetic variability, heritability, and genetic advance as a percentage of the mean (GAM), for understanding the breeding potentiality of $L$. longiflorum genotypes based on their performance for growth and flowering traits, so that pre-breeding scheme could be executed properly. The estimated genotypic coefficient of variation (GCV) and phenotypic coefficient of variation (PCV) value, along with heritability estimate and GAM, revealed that almost all studied traits besides flower diameter were controlled by additive gene action. For these traits, improvement would be possible through the selection after cross-breeding among these genotypes. The choice of genotypes for the hybridization scheme could be made based on the mean performance of those genotypes for the particular traits of the breeding scheme.
\end{abstract}

* Corresponding author

E-mail: jonghwa@kangwon.ac.kr (Jong-Hwa Kim)

Peer review under responsibility of Journal of Experimental Biology and Agricultural Sciences.

Production and Hosting by Horizon Publisher India [HPI] (http://www.horizonpublisherindia.in/).

All rights reserved.
All the articles published by Journal of Experimental Biology and Agricultural Sciences are licensed under a Creative Commons Attribution-NonCommercial 4.0 International License Based on a work at www.jebas.org.

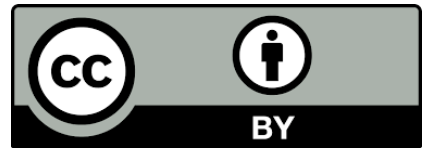




\section{Introduction}

Lilium longiflorum Thunb. is one of the species of the genus Lilium which consists of more than 110 species (Mc Rae, 1998; Dhiman et al., 2018). It belongs to the family Liliaceae and is found endemic to the southernmost Japanese Ryukyu Islands and the eastern seacoast and satellite islands of the mainland of Taiwan (Miller, 1993; Okazaki, 1996; Mc Rae, 1998; Hiramatsu et al., 2001). Though it was first reported in Europe in 1974, and it became famous as Easter lily worldwide; in the USA, it is used as a potted flower and used to force for the special day 'Easter' usually falls in April. It is taxonomically grouped into the subsection of the section Leucolirion or trumpets, representing 11 species (Dhiman et al., 2018). Nowadays, these are widely regarded as species of great importance for world Horticulture. $L$. longiflorum cultivars are famous for their large and trumpet-shaped flowers, besides strong fragrant white colored-flowers, and due to the early flowering habit year-round forcing cultivation capability are some of the distinguishing characteristics (Mc Rae, 1990). It is one of the primary sources of cut flowers during religious holidays in countries like the Netherland, Israel, Japan, and Korea (Grassotti \& Gimelli, 2011).

According to Matthews (2007) until 2005, more than 14000 cultivars have been developed and cultivated worldwide. Since then, hundreds of new cultivars have been grown and registered every year. Lilium breeding doesn't have so long a history. It has started in the first decennia of the $20^{\text {th }}$ century by producing the intersectional hybrids of the Sinomartagon section firstly in Japan and the USA (VanTuyl \& Arens 2011). After the development of appropriate pollination, embryo rescue and polyploidization technology interspecific hybridization has been started (Ki-Byung \& Van Tuyl, 2006; Van Tuyl et al., 2002). There are seven primary lily hybrids viz. O, A, L, T, LA, LO, and OT. Among these hybrid groups, Orientals $(\mathrm{O})$ are supposed to be the first hybrid groups which later on replaced by OT hybrids. Based on this experience, it was predicted that Asiatic (A) hybrids largely would be replaced by the LA hybrids, and the longiflorums (L) hybrids replaced by LO hybrids (Van Tuyl \& Arens, 2011; Dhiman et al., 2018). In this context, many commercial cultivars have been produced by interspecific hybridization to get the diverse cut flower traits and mainly propagated by vegetative methods (Mc Rae, 1998). In the context of recent breeding trends of interspecific hybridization, longiflorum hybrids and their commercial cultivars play a vital role in developing new cultivars in the competitive flower market of the world. There are so many cultivars available in longiflorum hybrids with their distinct growth and flowering traits. With these aspects, it deserves crucial to evaluate the performance of those cultivars in terms of growth and flowering habits, which would be beneficial for breeders to decide on the further development of an interspecific hybridization scheme. This study evaluated the growth and flowering traits of 16 cultivars/breeding lines to monitor their performance for these traits and for screening out them for the further breeding program (Table 1).

Table 1 List of used Lilium longiflorum Thunb. genotypes and their special remarks

\begin{tabular}{|ccccc|}
\hline S.N. & Genotype & Denotation & Flower color & Special remarks \\
\hline 1 & Bright tower (BT) & CV & White & Upward directional, Mid flowering habit \\
\hline 2 & Faith & CV & Pink & Upward, early flowering habit \\
\hline 3 & Global beauty & CV & White & Upward, Mid flowering habit \\
\hline 4 & Global village & CV & White & Upward, early flowering habit \\
\hline 5 & Georgia & CV & White & Side facing, very early flowering habit \\
\hline 6 & Gelria & CV & White & Side facing, very early flowering habit \\
\hline 7 & Lankon & CV & White, Brown mixed & Very early and pendant \\
\hline 8 & Hinomoto upward(HU) & Breeding line & White & Upward facing, early flowering habit \\
\hline 9 & Ishaghaki (IS) & Breeding line & White & Upward directional, Mid flowering habit \\
\hline 10 & White American (WA) & CV & White & Upward facing, early flowering habit \\
\hline 11 & White heaven & CV & White & Upward directional, early flowering habit \\
\hline 12 & White tower & CV & White & Upward directional, early flowering habit \\
\hline 13 & White trumph & CV & White & Side facing, Mid flowering habit \\
\hline 14 & Watch up & CV & White & Upward directional, early flowering habit \\
\hline 15 & Woori tower & CV & White & Upward facing, early flowering habit \\
\hline 16 & $12-1$ & Breeding line & White & Upward facing, late-flowering habit \\
\hline
\end{tabular}

Journal of Experimental Biology and Agricultural Sciences http://www.jebas.org 


\section{Materials and Methods}

\subsection{Plant material}

The plant materials employed for this study represented 13 different cultivars (CVs) and three breeding lines of L. longiflorum (Table 1). These cultivars and breeding lines were obtained from the floricultural breeding laboratory under the Department of Horticulture, Kangwon National University (KNU), South Korea.

\subsection{Experimental setup and raising the plant materials}

The commercial-sized bulbs $(10-15 \mathrm{~mm})$ of all genotypes selected in this experiment were grown for the evaluation inside the plastic house laid out in the randomized complete block design (RCBD) with three replications (Table 1). The genotypes were grown in multiple beds measuring $30 \mathrm{~m}$ in length and $1 \mathrm{~m}$ in width containing well-crushed coco-peat as growth media. The bulbs of all genotypes were planted using the planting net maintaining plant to plant and row to row equidistance of $12.5 \mathrm{~cm}$. Each bed contained four drip irrigation hoses fitted along the lengthwise of the bed for the provision of irrigation. All the plant saplings of al genotypes were grown well, adopting standard seedlings growing cultural practices followed by local lily grower farmers to produce healthy plant saplings to achieve the proper results.

\subsection{Morphological observation and sampling}

The morphological observation of all studied growth and flowering traits has been carried out during the main flowering season viz. June (4th week onward), July, and August (up to the third week) for selecting the four reliable plants from each replication. The measurement of all ten traits was carried out based on the guidelines of lily register checklists as provided by Mathews (2007) and following the general method of Rai et al. (2018), sampling four plants from each replication and in total 12 plants of each genotype.

\subsection{Statistical analysis}

The data measured for all studied growth and flowering traits of all genotypes were first prepared using MS-Excel-2013 and then employed for analysis using TNAUSTAT statistical packages. The estimation of Variance (ANOVA), F test, and other variance components were carried out following the plant breeding general tools of the TNAUSTAT statistical package for the randomized complete block design (RCBD). Likewise, Duncan's multiple range test was estimated at the 5\% level of significance for the separation of estimated means of the treatments adopting the available designs, DMRT comparison tools of the TNAUSTAT statistical package (Manivannan, 2014). Furthermore, variance components viz. phenotypic, genotypic, and environmental variance and their variance coefficients were estimated according to the formula and detail methods provided by Burton \& Devane
(1953). Likewise, broad-sense heritability $\left(\mathrm{H}^{2}\right)$, genetic advance (GA), and genetic advance as percent of the mean (GAM) were estimated based on the formula given by Allard (1960).

\section{Results and Discussion}

\subsection{Analysis of variance (ANOVA) and components of variance}

The analysis for variance ( $\mathrm{F}$ test; Table 2 ) demonstrated that all the studied traits viz. height of the plant, diameter of the stem, leaf numbers, length of leaves, width of the leaves, flower number, duration of flowering, diameter of flower, length of bud, and the axis of flower revealed genotypes are significantly varied with each other $(\mathrm{P}<0.01)$. The results indicated that 16 studied genotypes were different in their potentiality to perform variable growth and flowering traits. The genotypic variance, phenotypic variance, environmental variance, and its components, genetic advance, and genetic advance as percent of the mean are presented in table 2. The estimated PCV for all studied growth and flowering traits was found slightly higher than GCV, indicating the impact of environmental effect on the expression of these traits. The magnitude of the estimated PCV and GCV of the studied growth and flowering traits in this study are ranged between 11.15 and 6.73 (lowest for flower diameter), and 45.08 and 45.01 (the highest for the angle of flower) respectively (Table 2). It is proof of the existence of substantial broadly based genetic variability. Based on classification as provided by Deshmukh et al. (1986), PCV and GCV values can be categorized into three categories i.e. high $(>20 \%)$, medium $(10-20 \%)$, and low $(<10 \%)$. According to the estimated PCV and GCV values in this experiment, out of the ten studied growth and flowering traits, four traits viz. number of leaves, leaf width, number of flowers, and the angle of flower had demonstrated higher PCV and GCV which ranged from 23.46 to 45.08. According to Khan et al., (2009), high PCV demonstrated the existence of huge scope for selection of the traits under study. On the other hand estimated higher GCV indicates the presence of exploitable genetic variability for these traits which may helpful for selection (Yadav, 2009). The results indicated that the tested genotypes had the more outstanding and practical possibility for improvement if these traits are considered during selection and hybridization. On the other hand, growth and flowering traits viz. plant height, stem diameter, leaf length, days to flowering, and bud length had demonstrated moderate PCV and GCV value which had ranged from 12.32 to 19.98 , thereby indicating the acceptable improvement could be obtained through selection and of these traits. While only one remaining trait viz. flower diameter demonstrated a moderate PCV value (11.15) and lower GCV value (6.73). Though GCA provides information on the genetic variability existing in quantitative traits, this is only not the criteria to determine the amount of variation that was heritable, but GCA, along with the heritability estimates, would give an exact picture of heritable variation. 
Table 2 ANOVA and estimation of a genetic component for growth and flowering traits in L. longiflorum genotypes

\begin{tabular}{|ccccccccccc|}
\hline Traits /Parameter & G. Mean \pm SEM & $\begin{array}{c}\text { LSD } \\
(5 \%)\end{array}$ & $\begin{array}{l}\text { CV } \\
(\%)\end{array}$ & F test & PCV $(\%)$ & GCV $(\%)$ & ECV $(\%)$ & H $^{2}(\%)$ & GA & GAM $(\%)$ \\
\hline Plant height(cm) & $78.77 \pm 1.20$ & 11.53 & 1.98 & $* *$ & 19.98 & 19.88 & 1.98 & 99.02 & 25.43 & 40.75 \\
\hline Stem diameter & $7.72 \pm 0.10$ & 0.98 & 1.92 & $* *$ & 16.26 & 16.14 & 1.92 & 98.61 & 2.41 & 33.02 \\
\hline No. of leaves & $56.87 \pm 1.20$ & 11.40 & 4.99 & $* *$ & 28.27 & 27.82 & 4.99 & 96.88 & 45.31 & 56.41 \\
\hline Leaf length & $11.98 \pm 0.20$ & 1.70 & 4.65 & $* *$ & 19.22 & 18.65 & 4.65 & 94.15 & 8.65 & 37.28 \\
\hline Leaf width & $1.95 \pm 0.0$ & 0.30 & 4.14 & $* *$ & 23.82 & 23.46 & 4.14 & 96.98 & 1.29 & 47.59 \\
\hline No. of flowers & $3.33 \pm 0.1$ & 0.70 & 6.95 & $* *$ & 27.95 & 27.07 & 6.95 & 93.82 & 3.57 & 54.02 \\
\hline Days to flowering & $78.43 \pm 0.8$ & 8.30 & 0.53 & $* *$ & 15.04 & 15.03 & 0.53 & 99.88 & 6.83 & 30.93 \\
\hline Flower diameter & $49.4 \pm 0.24$ & 2.39 & 8.89 & $* *$ & 11.15 & 6.73 & 8.89 & 36.42 & 26.36 & 8.36 \\
\hline Bud length & $14.8 \pm 0.1$ & 1.30 & 2.32 & $* *$ & 12.53 & 12.32 & 2.32 & 96.58 & 5.46 & 24.93 \\
\hline Angle of flower & $58.95 \pm 1.93$ & 19.05 & 2.65 & $* *$ & 45.08 & 45.01 & 2.65 & 99.65 & 25.65 & 92.55 \\
\hline
\end{tabular}

Abbreviation ANOVA=Analysis of variance, G.Mean=General Mean, SEM=standard error of mean, SD=Least significance difference, $\mathrm{CV}=$ Coefficient of variation, $\mathrm{PCV}=$ Phenotypic coefficient of variation, $\mathrm{GCV}=$ Genotypic coefficient of variation, ECV=Environmental coefficient of variation, $\mathrm{H}^{2}=$ Heritability, $\mathrm{GA}=$ Genetic advance, $\mathrm{GAM}=$ Genetic advance as percentage of mean

\subsection{Heritability}

It is one of the most important insights to decide for the breeders on selecting and improving any breeding scheme. According to Ndukauba et al. (2015), heritability provides an idea of the extent of genetic control for the expression of a particular trait and the reliability of phenotype in predicting its breeding value. Based on estimated heritability, it is easier to understand whether their presence between parents and offspring for a particular trait has strong (having high heritability) or low level of (low heritability) resemblances (Ranjan \& Gautam, 2018).

Based on the classification provided by Singh (2001), the obtained heritability can be categorized into very high, moderately high, medium, and low categories. In the current study, the estimation of broad-sense heritability for all studied growth and flowering traits had ranged from $36.42 \%$ (for flower diameter) to $99.88 \%$ (for days to flowering). Based on heritability classification, all the studied traits besides flower diameter had possessed very high heritability. There should have less environmental impact on the observed variation of these traits (Eid, 2009). The heritability estimation indicates the presence of a positive response of improvement through the selection of these traits.

\subsection{Genetic advance and Genetic advance as percent of the mean (GAM)}

The knowledge of heritability and genetic advance is more useful since heritability alone does not indicate the amount of genetic improvement resulting from the selection of individual genotypes (Gebregergs \& Mekbib, 2020). According to Ullah et al. (2012), higher heritability coupled with higher genetic advance is more useful than heritability alone. Further, according to the classification of Johnson et al. (1955), genetic advance as percentage of mean (GAM) can be categorized into three groups i.e. high $(>20 \%)$, moderate $(10-20 \%)$, and low $(0-10 \%)$. In this experiment, the estimated GAM had ranged from 8.36 (for flower diameter) to 92.55 (Table 2). Furthermore, almost all growth and flowering traits under study viz. plant height, stem diameter, number of leaves, leaf length, leaf width, number of flowers, days to flowering, bud length, and angle of flower had possessed high GAM while remaining one trait flower diameter had recorded low GAM as we have achieved high heritability along with high GAM for nine growth and flowering traits that these traits were controlled by additive gene action and thereby indicated the most effective condition for the selection process for the further breeding schemes (Tazeen et al., 2009; Ndukauba et al., 2015).

\subsection{Mean performances}

The estimated mean performance for ten growth and flowering traits demonstrated huge variability in these traits among the studied 16 L. longiflorum genotypes (Table 3 ). The plant height is one of the essential traits from the cut flower point of view; in this study, global beauty and white tower were found tallest than other remaining genotypes. Likewise, among the 16 genotypes, $L$. longiflorum cultivar 'White American (WA)' and breeding line IS (Ishaghaki) were found shortest for their mean performance in plant height. In the second estimated trait, i.e., stem diameter, we have discovered the thickest stem for white triumph while the thinnest stem was jointly recorded for Gelria and Georgia. Likewise, L. longiflorum cultivar' Global village' possessed the highest number of leaves while IS had the lowest number of leaves in their stems. The longest leaves were recorded for white heaven, and the shortest leaves were measured for the global village and Lankan. 
Table 3 The mean performance for major growth and flowering traits of L. longiflorum genotypes

\begin{tabular}{|c|c|c|c|c|c|c|c|c|c|c|}
\hline Traits /Genotypes & $\begin{array}{l}\text { Plant } \\
\text { height }\end{array}$ & $\begin{array}{c}\text { Stem } \\
\text { diameter }\end{array}$ & $\begin{array}{l}\text { No. of } \\
\text { leaves }\end{array}$ & $\begin{array}{l}\text { Leaf } \\
\text { length }\end{array}$ & $\begin{array}{l}\text { Leaf } \\
\text { width }\end{array}$ & $\begin{array}{l}\text { No. of } \\
\text { flowers }\end{array}$ & $\begin{array}{l}\text { Days to } \\
\text { flowering }\end{array}$ & $\begin{array}{c}\text { Flower } \\
\text { diameter }\end{array}$ & $\begin{array}{l}\text { Bud } \\
\text { length }\end{array}$ & $\begin{array}{l}\text { Angle of } \\
\text { flower }\end{array}$ \\
\hline Bright tower & $87.5^{\mathrm{c}}$ & $6.65^{\mathrm{i}}$ & $48.6^{\mathrm{f}}$ & $11.8^{\mathrm{gh}}$ & $2.3^{\mathrm{b}}$ & $2.5^{\mathrm{fg}}$ & $81.7^{\mathrm{f}}$ & $49.40^{\mathrm{bc}}$ & $14.7^{\mathrm{ef}}$ & $63.75^{\mathrm{g}}$ \\
\hline Faith & $62.8^{\mathrm{g}}$ & $9.69^{\mathrm{b}}$ & $57.3^{\mathrm{e}}$ & $11.1^{\mathrm{hi}}$ & $1.7^{\mathrm{e}}$ & $2.6^{\mathrm{fg}}$ & $74.3^{\mathrm{i}}$ & $45.15^{\mathrm{c}}$ & $14.8^{\mathrm{e}}$ & $85.00^{\mathrm{a}}$ \\
\hline Global beauty & $100.4^{\mathrm{a}}$ & $9.16^{\mathrm{c}}$ & $83.4^{\mathrm{b}}$ & $12.1^{\mathrm{fg}}$ & $2.3^{\mathrm{b}}$ & $3.4^{\mathrm{d}}$ & $88.5^{\mathrm{e}}$ & $59.80^{\mathrm{a}}$ & $16.3^{\mathrm{bc}}$ & $67.50^{\mathrm{f}}$ \\
\hline Global village & $71.1^{\mathrm{e}}$ & $7.28^{g}$ & $93.5^{\mathrm{a}}$ & $8.0^{\mathrm{k}}$ & $1.1^{\mathrm{g}}$ & $3.6^{\mathrm{d}}$ & $68.5^{\mathrm{k}}$ & $50.46^{\mathrm{bc}}$ & $10.9^{\mathrm{j}}$ & $82.50^{\mathrm{ab}}$ \\
\hline Georgia & $61.6^{\mathrm{g}}$ & $6.29^{\mathrm{j}}$ & $44.2^{\mathrm{fg}}$ & $12.1^{\mathrm{fg}}$ & $2.1^{\mathrm{c}}$ & $2.4^{\text {gh }}$ & $63.6^{1}$ & $44.70^{c}$ & $12.8^{\mathrm{h}}$ & $18.13^{\mathrm{i}}$ \\
\hline Gelria & $65.5^{\mathrm{f}}$ & $6.20^{\mathrm{j}}$ & $43.3^{\mathrm{gh}}$ & $14.1^{\mathrm{bc}}$ & $1.7^{\mathrm{e}}$ & $2.8^{\mathrm{f}}$ & $68.8^{\mathrm{k}}$ & $45.13^{\mathrm{c}}$ & $16.4^{\mathrm{bc}}$ & $26.88^{\mathrm{h}}$ \\
\hline Lankon & $92.3^{\mathrm{b}}$ & $7.23^{\mathrm{g}}$ & $71.1^{\mathrm{c}}$ & $7.7^{\mathrm{k}}$ & $1.5^{\mathrm{f}}$ & $3.6^{\mathrm{d}}$ & $60.4^{\mathrm{m}}$ & $44.78^{\mathrm{c}}$ & $11.7^{\mathrm{i}}$ & $11.67^{\mathrm{j}}$ \\
\hline Hinomoto upward & $68.8^{\mathrm{e}}$ & $6.72^{\mathrm{hi}}$ & $41.3^{\mathrm{hi}}$ & $11.7^{\mathrm{gh}}$ & $1.6^{\mathrm{ef}}$ & $2.5^{\mathrm{fg}}$ & $73.5^{\mathrm{j}}$ & $48.78^{\mathrm{bc}}$ & $13.5^{\mathrm{g}}$ & $78.75^{\mathrm{cd}}$ \\
\hline IS & $53.8^{\mathrm{h}}$ & $6.94^{\mathrm{h}}$ & $38.5^{\mathrm{i}}$ & $14.6^{\mathrm{b}}$ & $2.0^{\mathrm{cd}}$ & $2.2^{\mathrm{h}}$ & $75.4^{\mathrm{h}}$ & $46.73^{\mathrm{bc}}$ & $15.9^{\mathrm{cd}}$ & $68.33^{f}$ \\
\hline White American & $56.1^{\mathrm{h}}$ & $6.66^{\mathrm{i}}$ & $47.4^{\mathrm{fg}}$ & $13.2^{\mathrm{cd}}$ & $1.9^{\mathrm{d}}$ & $3.1^{\mathrm{e}}$ & $73.1^{\mathrm{j}}$ & $47.16^{\mathrm{bc}}$ & $16.7^{\mathrm{b}}$ & $71.25^{\mathrm{e}}$ \\
\hline White Heaven & $92.6^{\mathrm{b}}$ & $8.33^{\mathrm{d}}$ & $45.6^{\mathrm{fg}}$ & $15.6^{\mathrm{a}}$ & $2.4^{\mathrm{b}}$ & $2.5^{\mathrm{fg}}$ & $89.4^{\mathrm{d}}$ & $55.27^{\mathrm{ab}}$ & $17.3^{\mathrm{a}}$ & $28.12^{\mathrm{h}}$ \\
\hline White tower & $98.1^{\mathrm{a}}$ & $8.18 \mathrm{~d}^{\mathrm{e}}$ & $69.9^{\mathrm{cd}}$ & $13.0^{\mathrm{de}}$ & $1.7^{\mathrm{e}}$ & $4.3^{\mathrm{c}}$ & $74.3^{\mathrm{i}}$ & $49.99^{\mathrm{bc}}$ & $15.6^{\mathrm{d}}$ & $72.50^{\mathrm{e}}$ \\
\hline White trumph & $84.9^{c}$ & $10.57^{\mathrm{a}}$ & $58.9^{\mathrm{e}}$ & $13.9^{\mathrm{bc}}$ & $2.0^{\mathrm{cd}}$ & $4.7^{\mathrm{b}}$ & $76.3^{g}$ & $54.26^{\mathrm{ab}}$ & $15.6^{\mathrm{d}}$ & $26.27^{\mathrm{h}}$ \\
\hline Watch up & $90.2^{\mathrm{b}}$ & $7.70^{\mathrm{f}}$ & $54.3^{\mathrm{e}}$ & $10.7^{\mathrm{i}}$ & $2.1^{\mathrm{c}}$ & $3.5^{\mathrm{d}}$ & $90.1^{\mathrm{c}}$ & $49.30^{\mathrm{bc}}$ & $14.1^{\mathrm{f}}$ & $81.27^{\mathrm{bc}}$ \\
\hline Woori tower & $92.8^{\mathrm{b}}$ & $8.03^{\mathrm{e}}$ & $65.4^{\mathrm{d}}$ & $12.9^{\mathrm{ef}}$ & $1.7^{\mathrm{e}}$ & $4.6^{\mathrm{b}}$ & $92.0^{\mathrm{b}}$ & $50.72^{\mathrm{bc}}$ & $16.3^{\mathrm{bc}}$ & $76.25^{\mathrm{d}}$ \\
\hline $12-1$ & $81.8^{\mathrm{d}}$ & $7.91^{\mathrm{ef}}$ & $47.2^{\mathrm{fg}}$ & $9.1^{\mathrm{j}}$ & $3.1^{\mathrm{a}}$ & $5.0^{\mathrm{a}}$ & $104.8^{\mathrm{a}}$ & $48.77^{\mathrm{bc}}$ & $14.2^{\mathrm{ef}}$ & $85.00^{\mathrm{a}}$ \\
\hline G Mean & 78.8 & 7.72 & 56.9 & 12.0 & 1.9 & 3.3 & 78.4 & 49.40 & 14.8 & 58.95 \\
\hline SEM & 1.2 & 0.10 & 1.2 & 0.2 & 0.0 & 0.1 & 0.8 & 0.24 & 0.1 & 1.93 \\
\hline
\end{tabular}

In the case of another growth trait, leaf width; the broadest leaves were measured for 12-1, while narrowest leaves were found in the stem of 'global village.' Additionally, for more numbers of flowers that deserved vital importance from the cut flowers point of view, the highest numbers of flowers were found for 12-1, while the fewest number of the flower were recorded in the stem of IS. Lankan has very early flowering habit with average days to flowering 60.4 days while very late flowering cultivar was recorded for 12-1 with 104.8 days to the flowering period from transplanting bulbs. On average, most enormous flowers were found for global beauty, while smaller flowers were recorded for Faith, Georgia, Gelria, and Lankan. The longest bud was measured for white heaven, while the shortest buds were calculated for the global village. The last and most important trait, ' flower direction,' is synonymously used as the attitude of the floral axis; most upward-facing flowers were found for Faith while pendulous flower habit 'Lankan' flowers consisted lowest flower angle. The mean performance evaluation is one of the insights which emphasize the selection of the progeny based on the superior performance of a particular trait of interest. Rai et al. (2018) revealed varied mean performances are due to the genetic variability of the studied genotypes.

\section{Conclusions}

Results of the study can be concluded that all the sixteen genotypes were statistically significant for all the studied growth and flowering traits, thereby revealing the presence of an enormous amount of genetic variability. The characteristics viz. number of leaves, leaf width, numbers of flowers, and the angle of flower had possessed high GCV and PCV along with high heritability and GAM while traits viz. plant height, stem diameter, leaf length, days to flowering, and bud length had demonstrated moderate GCV and PCV value along with high heritability and GAM thereby indicating the potentiality for the selection and improvement of these traits. On the other hand, as flower diameter had possessed lower GCV and PCV coupled with low heritability and GAM, there is a limitation for this trait for selection and improvement through cross-breeding.

\section{Acknowledgements}

This study was carried out with the support of the GSP Project No. 213007-05-5-SBM10, the Ministry of Agriculture, Food and Rural Affairs, Republic of Korea. 


\section{Conflict of Interest}

There is no conflict of interest between the authors about the content of the article

\section{References}

Allard RW (1960) Principles of Plant Breeding. John Wiley and Sonc Inc., New York, USA.

Burton GW, Devane E (1953) Estimating heritability in tall fescue (Festuca arundinacea) from replicated clonal material 1. Agronomy Journal 45(10):478-481.

Deshmukh S, Basu M, Reddy P (1986) Genetic variability, character association and path coefficients of quantitative traits in Virginia bunch varieties of groundnut. Indian Journal of Agricultural Sciences 56(12):816-821.

Dhiman MR, Moudgil S, Parkash C, Kumar R, Kumar S (2018) Biodiversity in Lilium: A Review. International Journal of Horticulture 8(8): 83-97.

Eid MH (2009) Estimates of heritability and genetic advance of yield traits in wheat (Triticum aesivum L.) under drought conditions. International Journal of Genetics and Molecular Biology 1(7): 115 - 120.

Gebregergs G, Mekbib F (2020) Estimation of genetic variability, heritability, and genetic advance in advanced lines for grain yield and yield components of sorghum [Sorghum bicolor (L.) Moench] at Humera, Western Tigray, Ethiopia. Cogent Food \& Agriculture 6(1):1764181.

Grassotti A, Gimelli F (2011) Bulb and cut flower production in the genus Lilium: current status and the future. Acta Horticulture 900: 21-36. DOI:10.17660/ActaHortic.2011.900.1.

Hiramatsu M, Ii K, Okubo H, Huang KL, Huang CW (2001) Biogeography and origin of Lilium longiflorum and L. formosanum (Liliaceae) endemic to the Ryukyu Archipelago and Taiwan as determined by allozyme diversity. American Journal of Botany 88 : 1230-1239.

Johnson HW, Robinson H, Comstock R (1955) Estimates of genetic and environmental variability in soybeans. Agronomy Journal 47(7):314-318.

Khan A, Kabir MY, Alam MM (2009) Variability, correlation, path analysis of yield and yield components of pointed gourd. Journal Agricultural Rural Development 7 (1\&2): 93-98.

Ki-Byung L, Van Tuyl JM (2006) Lily, Lilium hybrids. P.517-537. In: Anderson NO (Ed.), Flower breeding and genetics: issues, challenges and opportunities for the 21st century, Chapter 19. Kluwer Academic Publishers, Dordrecht.
Manivannan N (2014) TNAUSTAT-Statistical Package. Retrieved from https://sites.google/site/tnaustat access on 20 July, 2021.

Matthews V (2007) The International Lily Register and Checklist. RHS London, Fourth Edition.

McRae EA (1990) American Lily Hybridizing-an Historical Review. In: Hayward AF (Ed) Lilies and Related Plants, Supplement, 1990.P 5th International Lily Conference, London, July, 1989, Royal Horticultural Society Lily, Pp.: 29-40.

McRae EA (1998) Lily species. In Lilies, A Guide for Growers and Collectors, Timber Press, Portland, Oregon. USA. Pp. 239-257.

Miller WB (1993) Lilium longiflorum. In: De Hertogh A, Le Nard M (Ed.) The physiology of flower bulbs, 391-422.

Ndukauba J, Nwofia GE, Okocha PI, Ene-Obong EE (2015) Variability in egusi-melon genotypes (Citrullus lanatus [Thumb] Matsum and Nakai) in derived savannah environment in SouthEastern Nigeria. International Journal of Plant Research 5(1):19-26.

Okazaki K (1996) Lilium species native to Japan, and breeding and production of Lilium in Japan. Acta Horticulturae 414:81-92.

Rai R, Shrestha J, Kim JH (2018) Combining Ability and Gene Action Analysis of Quantitative Traits in Lilium× formolongi. Journal of Agricultural, Life and Environmental Sciences 30:131-143.

Ranjan S, Gautam A (2018) Heritability Estimate. In: Vonk J, Shackelford $\mathrm{T}$ (Eds.) Encyclopedia of Animal Cognition and Behavior. Springer, https://doi.org/10.1007/978-3-319-47829-6_6-1.

Singh BD (2001) Plant Breeding principles and methods. Kalyani Publishers, New Delhi, India.

Tazeen M, Nadia K, Farzana NN (2007) Heritability, phenotypic correlation and path coefficient studies for some agronomic characters in synthetic elite lines of wheat. Journal of Food, Agriculture and Environment 7 (3\&4): 278 - 282.

Ullah, MZ, Hasan MJ, Chowdhury AZMKA, Saki AI,Rahman AHMA (2012) Genetic variability and correlation in exotic Cucumber (Cucumis sativus L.) varieties. Bangladesh Journal of Plant Breeding and Genetics 25(1):17-23.

Van Tuyl JM, Arens P (2011) Lilium: Breeding History of the modern cultivar assortment. Acta Horticulturae 900:223-230.

Van Tuyl JM, Chung MY, Chung JD, Lim KB ( 2002) Introgression studies using GISH in interspecific Lilium hybrids of L. Longiflorum $\times$ Asiatic, L. longiflorum $\times$ L. 227 rubellum and $L$. auratum $\times L$. henryi. Yb. North American Lily Society 55:17-22, 70-72.

Yadav YC, Kumar S, Bisen B, Dixit SK (2009) Genetic variability, heretability and genetic advance for some traits in cucumber Indian Journal of Horticulture 66(4):488-491. 